\title{
When The Scientist Presents
}

An Audio and Video Guide to Science Talks 
This page intentionally left blank 


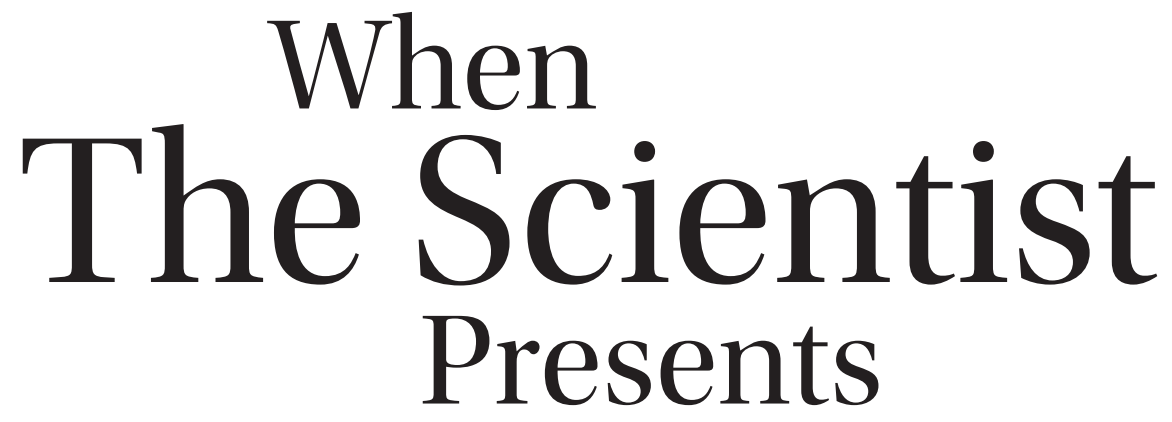

\section{An Audio and Video Guide to Science Talks}

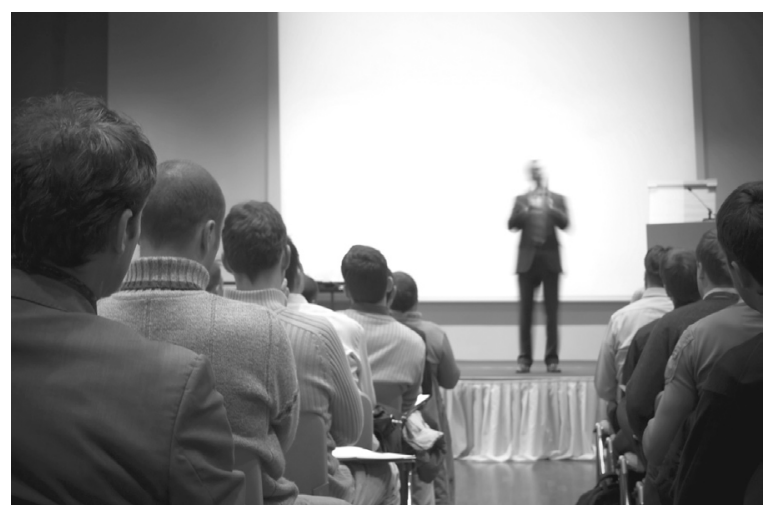

\section{Jean-Luc Lebrun}

Trainer of researchers and scientists from A*STAR Research Institutes, Singapore Former Director, Apple-ISS Research Centre, Singapore 


\section{Published by}

World Scientific Publishing Co. Pte. Ltd.

5 Toh Tuck Link, Singapore 596224

USA office: 27 Warren Street, Suite 401-402, Hackensack, NJ 07601

UK office: 57 Shelton Street, Covent Garden, London WC2H 9HE

\section{British Library Cataloguing-in-Publication Data}

A catalogue record for this book is available from the British Library.

\section{WHEN THE SCIENTIST PRESENTS \\ An Audio and Video Guide to Science Talks \\ (With DVD-ROM)}

Copyright (ङ 2010 by World Scientific Publishing Co. Pte. Ltd.

All rights reserved. This book, or parts thereof, may not be reproduced in any form or by any means, electronic or mechanical, including photocopying, recording or any information storage and retrieval system now known or to be invented, without written permission from the Publisher.

For photocopying of material in this volume, please pay a copying fee through the Copyright Clearance Center, Inc., 222 Rosewood Drive, Danvers, MA 01923, USA. In this case permission to photocopy is not required from the publisher.

ISBN-13 978-981-283-919-0

ISBN-10 981-283-919-4

ISBN-13 978-981-283-920-6(pbk)

ISBN-10 981-283-920-8 (pbk)

Typeset by Stallion Press

Email: enquiries@stallionpress.com

Printed in Singapore. 


\section{PREFACE}

\section{Vladimir's backstage exit}

Vladimir brings the last slide on the screen, a bright white "Q\&A" on a dark background. Finally moving his eyes away from the computer screen, he says, "Thank you for your attention. Any questions?"

About ten to fifteen people are scattered in a room too big for an audience this small. Most of them are sitting either in an aisle seat or in the last row, ready to make a quick exit. Some already have. As he waits, he feels quite uncomfortable. Not one hand goes up. In the front row, his supervisor is packing up, ready to leave. After an unbearable foursecond silence, Vladimir looks sideways to the chairperson who, after glancing furtively at his watch, rescues Vlad with a loud "Thank you Dr. Toldoff". Vladimir presses the spacebar one last time. The screen goes dark, Microsoft PowerPoint exits front stage, and Vladimir exits backstage.

Outside the conference room, during the coffee break, Vladimir approaches his supervisor, a burning question on his mind.

"How did I do?" he asks.

"You did fine", responds his supervisor while avoiding eye contact.

To get an honest answer, Vladimir changes his question.

"Did I do as well as Dr. Sorpong?"

The supervisor now looks at him, condescendingly.

"As well as Dr. Sorpong? Not quite. I think it would be good if I added presentation skills as an objective in your upcoming performance review. Quite frankly, you need more confidence, more dynamism, better slides, 
and you need to work on that Russian accent of yours. I am used to it, but the audience clearly isn't."

Vladimir sighs.

"Are you sending me to a presentation skills class?"

"That could be arranged."

"In Hawaii?"

"Don't push it, Vlad."

Greetings! Your name may not be Vladimir, and you may not be Russian, but you are a scientist, and that tells me a lot about you. You are someone who is not satisfied with status quo situations. You suspect there is no such thing as a presentation skills gene in anyone's DNA and you are convinced that these skills are acquired and improved through learning and doing. You have seen great presenters tackling the most difficult topics without effort and with great result. If they can do it, so can you! Great!

Your future skills are sleeping, waiting to be brought to life in this book and the companion DVD. They are here for you, ready to serve you, ready to turn you into a great presenter. How do you access them? Just rub your mind against the words of these pages, and review the media on the DVD. These skills can become yours.

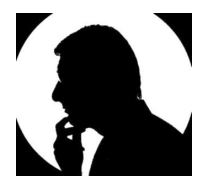

Where there are exercises, do them; where there are checklists, follow them;

where there are videos, watch them; 


\section{where there are podcasts, listen to them;}

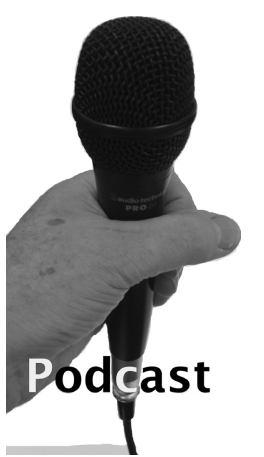

where there are podcasts, listen to them;

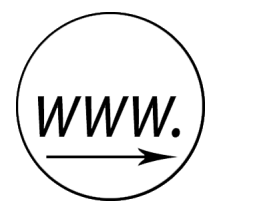

and where there are websites, visit them.

But most importantly, apply these newfound skills as early as possible.

In this book, we will imagine that your task is to present your paper at a scientific meeting. If all goes well, your presentation will end up being quite different from your paper. It cannot be otherwise because the paper is no longer essential this time, but you are. Danish professor Peter Sigmund of Odessa University, a man who must have seen many bad presentations, wrote a tongue-in-cheek column in Physics Today entitled "Fifteen Ways to Get Your Audience to Leave You". The eighth point of advice recommends that you "ignore the inherent difference that exists between oral and mritten communication". Since you want your audience to stay, you want to know the difference. That is your first task. For this task, consult the first four book chapters as well as the DVD. They reveal how to select the contents for your slides and prepare you for the slide design and creation stage covered in chapters five and six. The DVD provides what the book cannot: dynamic media rich in colours and PowerPoint/Keynote DIY (do it yourself) techniques. The final task will be for you to visualise yourself presenting and answering questions from the audience. This part is essentially dynamic. Book chapters 7 to 10 as well as DVD tutorials build up your personal skills and confidence. 
This book is great, as an in vitro tool. It is up to you to make it come alive in vivo, in situ, not in the test tube of a classroom, but in a real conference setting. The good news is that presentation skills can be learned. Among the hundreds of talented research scientists from A*STAR Research Institutes (Singapore's Agency for Science, Technology, And Research) who attended the presentation skills class based on this book, not one felt hopeless. And yet, the challenge they had to face was colossal. The presentation of each paper was only 7 minutes long. It took place in a large auditorium in front of scientists from different institutes. Engineers presented to Biologists, Chemists to Computer Scientists, Immunologists to Technologists. They had to be clear and interesting to people from extremely diverse background and convince the audience of the worth of their scientific contribution. As if that was not difficult enough, each had to go through a gruelling 8-minute Q\&A after their presentation, where their authority, competence, knowledge, and nerves were tested to the limit. Under such harsh conditions, success was far from being guaranteed. But succeed, they did. It was possible in parts thanks to the many live rehearsals each had in front of a smaller audience made up of experts and non-experts. It was also because they spent close to a full day simplifying and illustrating the one point each of their slides made until it was understandable and legible to all. It was because they understood that, in scientific presentations, the presenter's role is to be a host who keeps a tight rein on the computer co-host. Finally, it was because they had been coached on how to face the audience, rephrase and answer questions from experts, non-experts, and troublemakers; questions that were sometimes relevant and sometimes not, sometimes hostile or incomprehensible and sometimes over-friendly.

It is their success that gives me the confidence that you can succeed too. To make learning fun, I pepper the pages here and there with the story of my scientist friend, Vladimir, a fictional character who excels at being a bad presenter. Actually, Vladimir is a mosaic, a montage, a collage, made up of hundreds of little bits and pieces of things presenters do that they shouldn't. $\mathrm{He}$ is the ultimate counter-example. If you sometimes recognise yourself in him, it is through pure coincidence, of course. And if your name happens to be Vladimir, don't feel bad, my Vladimir does not have the same last name. Have fun. It's time to turn the page to chapter 1. Happy reading! 


\section{CONTENTS}

Preface v v

Part I: Content Selection $\quad 1$

Chapter 1: Paper and Oral Presentation: The Difference 3

- The Spoken Word vs. The Written Word 4

- Collective Audience but Individual Expectations 7

- Captive Audience Trapped in Time and Space 14

- Imposed Pace and Rigid Slide Sequence 17

- You, Personality, Face, and Voice 19

Chapter 2: Content Filtering Criteria $\quad 24$

- The Audience Expects the Presentation to be About 27 Its Title

- All Contributors Expect to be Acknowledged 31

- Novelty, Applicability, and Time to Explain 33 are the Main Content Filters

Part II: Audience Expectations $\quad 37$

Chapter 3: General Audience Expectations 39

- No Disconnect 39

- No Strain 42

- No Boredom 49

- No Disregard 50 
Chapter 4: Scientific Audience Expectations

- Digestible Scientific Content 53

- Believable Content and Credible Scientist 56

- Useful Scientific Content 62

Part III: The Slides $\quad 65$

Chapter 5: Five Slide Types, Five Roles $\quad 67$

- Title Slide - The Name Card 68

- Hook Slide - The Attention Grabber 73

- Map Slide - The Head's Up Option 79

- Story Slides - The Proven Claims 83

- Conclusion Slide - The Promised Items 91

$\begin{array}{ll}\text { Chapter 6: Slide Design } & 97\end{array}$

- Design for Slide Legibility 97

- Design for Audience Attention 124

- Design for Presenter Flexibility 135

- Design for Persuasion 144

Part IV: The Presenter 149

Chapter 7: The Master of Tools 151

- Screen, Pointers, Mikes, and Lectern 151

- Audio and Light Control 164

- Presentation Software (Keynote and PowerPoint) 164

Chapter 8: Scientist and Perfect Host 169

- The Attentive Host 171

- The Visible Host (and the Co-Host) 173

- The Hospitable Scientist 179

Chapter 9: The Grabbing Voice 182

- Speak with Confidence 182

- Speak for Intelligibility 187

- Speak for Attention 194

- Speak for Persuasion 196 
Chapter 10: The Answerable Scientist 200

- The Process of Answering Questions 204

- Three Troublesome Questioning Styles and How 217 to Deal with Them

- Difficult and Dangerous Questions 222

- Typical Questions from Specific Groups 237

- Techniques for Fast Answer Support 239

$\begin{array}{ll}\text { Appendix } & 245\end{array}$

$\begin{array}{ll}\text { Index } & 249\end{array}$ 